(Aus dem Institnt für Pathologie zu Batavia, Director Dr. C. Eykman.)

\title{
Ueber den Einfluss gelöster Stoffe auf die rothen Blutzellen, in Verbindung mit den Erscheinungen der Osmose und Diffusion.
}

Von

1). G. Gryns.

Mit 1 Textfigur.

Als ich vor wenigen Jahren meine Untersuchungen iiber das specitische Gewicht von Blut und Plasma der Tropenbewohner begann ${ }^{1}$ ), stellte ich mir als weiteres Ziel, auch das Volumen der rothen Blutkörperchen nach der Centrifugirmethode zu bestimmen.

Weil keiner der Forscher, die mit dem Haematokrit arbeiteten, meiner Meinung nach, bei der Wahl der Mischfliussigkeit geniugend beriicksichtigten, dass dieselbe eine gleiche wasseranziehende Kraft (osmotischen Druck) wie das Plasma haben muss, so beschloss ich in erster Linie zu untersuchen, wie weit der Einfluss sich erstreckt, den verschiedene Lösungen mit ungleichem osmotischen Druck auf das Volumen des Bodensatzes haben.

Die bei diesen Versuchen erlangten Resultate ermunterten mich, in der einmal eingeschlagenen Richtung weiter fort zu schreiten, als ich anfangs beabsichtigte.

Bevor ich jedoch zu einer Besprechung der wahrgenommenen Erscheinungen ïbergehe, wird eine kurze Uebersicht iber Osmose erwünscht erscheinen. (Vgl. Ostwald, Lehrbuch der allgem. Chemie, Bd. I. S, 651 ff.)

Wenn zwei Lösungen mit einander in Berührung stehen, so kann Uebergang von Moleciilen von der einen zur anderen, bezw. Austausch von Moleciilen zwischen den beiden stattfinden. Indem

1) Virchow's Archiv. Bd. 139. 
wir nur die Fälle berücksichtigen, wobei das nämliche Lösungsmittel gebraucht wurde, giebt es dabei Folgendes zu unterscheiden:

1. Die beiden Flüssigkeiten sind durch keine Zwischenwand von einander getrennt oder nur durch eine solehe, die Menstruum und gelösten Stoff mit gleicher Leichtigkeit durchtreten lässt. - Diffu sion.

2. Es ist eine poröse Zwischenwand vorhanden, die zwar das Lösungsmittel, niclit aber den gelösten Stoff durchlässt. Osmose in engerem Sinn ( $P$ feffer).

3. Die Zwischenwand ist für Lösungsmittel und gelösten Stoff beide permeabel, für letzteren aber in geringerem Maasse. Diosmose; Endosmose und Exosmose (Graham).

Ueber den ersten Fall, die Diffusion, herrscht keine Meinungsverschiedenheit. Die gelösten Stoffe verbreiten sich mit einer Geschwindigkeit, die ihrer Concentration proportional ist und weiter bedingt wird durch die Reibung, welche sich den bewegenden Moleciilen entgegenstellt.

Zur Entwicklung eines hydrostatischen Druckunterschiedes, wie er sich in den beiden anderen Fällen zeigt, bietet sich hier nicht die Gelegenbeit.

Der zweite Fall ist zuerst von Pfeffer einer eingehenderen Untersuchung unterworfen: Er bezieht sich auf die einfachste ans der ganzen Gruppe der unter Osmose zusammengefassten Erscheinungen und ist deshalb am meisten fül ein genaueres Studium geeignet.

Nehmen wir ein Gefüss, dessen Wand den zu untersuchenden Körper nicht durehlässt, wohl aber' das Menstruum (P feffer'sche Thonzelle) und setzen dies mit einer Steigröhre oder einem geschlossenen Manometer in Verbindung - letzteres verdient den Vorzug, weil alsdann die Lösung im Gefässe während des Versuchs weniger verdünnt wird - so sehen wir, wenn die Lösung sich innerhalb des Gefässes, das Menstruum dagegen sich ausserhalb desselben befindet, dass letzteres solange durch die Wand ins Innere des Gefässes dringt, bis ein bestimmter Druck erreicht ist.

Van t' Hoff kam zu dem Schluss, dass die Ursache des osmotischen Druckes im gelösten Stoffe liege und unabhängig sei von der Natur der Membran. Derselbe ist proportional der Zahl 
der aufgelösten Molecïle (resp. Moleciile und "Jonen" - worüber später) und der absoluten Temperatur.

Gelöste Stoffe üben also denselben Druck ans wie sie unter gleichen Umstäuden von Temperatur und Volumen in Gasform offenbaren wiurden. Dieser Druck ist gegen die gesanmte Oberfläche der Flinssigkeit gerichtet und muss als ein Anprallen der Molecuile gegen dieselbe, bezw. gegen die Wand, welche die Fliissigkeit begrenzt, angesehen werden, wie solehes ebenso bei der Theorie uiber die Gase der Fall ist.

Der osmotische Druck ist bereits bei mässiger Concentration ein sehr bedentender; für eine wässerige Lösung von $17 \%$ Ammoniak beträgt sie schọ 224 Atmosphären. Dass durch diesen hoben Druck die Gefässe, in denen die Lösungen aufbewahrt werden, nicht springen, lat seinen Grund darin, dass die Spannung der Flüssigkeitsoberfläche, der sogenannte normale Binnendruck, in umgekehrter Richtung thätig und weit grösser ist.

Ist jedoch eine Lösung durch eine Zwischenwand vom Lösungsmittel geschieden und lässt diese Wand wohl das Menstruum, nicht aber den gelösten Stoff durch, dann wird, sobald das Menstruum durch die Scheidewand gedrungen und mit der Lösung in Beriuhrung gekommen ist, an diesen Stellen die freie Flïssigkeitsoberfläche und mit ihr der normale Binnendruck wegfallen.

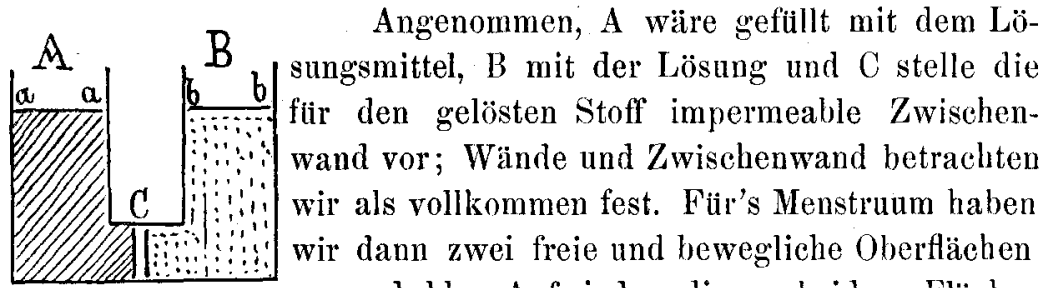
aa und bb. Auf jeder dieser beiden Flächen wirkt der normale Binnendruck, und weil der Drack sich gleichmässig ïber die ganze Flïssigkeit fortpflanzt (Gesetz von Pascal), ist die Bedingung des Gleichgewichts unabbängig von der relativen Grösse dieser beiden Oberflächen. Das System wird also, was den Binnendruck betrifft, im Gleichgewichte stehen, wenn die Höhen aa und bb umgekehrt proportional den specifischen Gewichten sind. Nun aber befindet sich im Gefäss B noch der gelöste Stoff, dessen Moleciule sich in der Flüssigkeit frei bewegen und durch ihren Anprall einen Druck anf alle Winde aus- 
iben. Dieser Druck wird an allen ïbrigen Stellen durch den grossen normalen Binnendruck iberwunden, nor bei $C$, woselbst, soweit die beiden Flissigkeiteu einander berithen, der Binnendruck wegfällt, wird der osmotische Druck gretragen durch die Zwischenwand, welche die Moleciile des gelösten Stoffes nicht durchdringen lässt. Der Druck des gelösten Stoffes kann sich also zum Gefïsse 1 nicht fortpflanzen. Im Gefässe B herrscht ein Druck, welcher gleich ist dem normalen Binnendruck, vermindert am den des ge. lösten Stoffes; im Gefäse $\Lambda$ herrscht nur der normale Binnendruck. Durch die Zwischenwand wird also dic Fliissigkeit aus $A$ nach B getrieben und zwar solange bis bei offenen Gefäsen der hydrostatische (bei geschlossenem Gefässe B, mit dem Manometer verbunden, der manometrische) Druck dem osmotischen Druck das Gleichgewicht hält.

Geht dagegen der gelöste Stoff olne Widerstand durch die Zwischenwand, dann wird auch sein osmotischer Druck ungehindert zum andern Gefässe sich fortpflanzen, und in diesen Falle nehmen wir keine durch diesen Druck verursachte Flissigkeitsbewegung wahr: Der Zustand des Gleichgewichts wird lediglich durch die hydrostatischen Gesetze bedingt.

Sind im Gefässe eine Anzahl von nicht durcbdringenden Stoffen in Lösung begriffen, deren Moleciile chemisch nicht aufeinander einwirken, dann ist der resultirende osmotische Druck gleich der Summe der Partiardrucke, welche die Stoffe jeder für sich ausüben: also auch hier wieder dasselbe Gesetz wie bei den Gasen.

Sind jedoch in der Lösung auch Stoffe vorhanden, welche durch die Poren der Scheidewand dringen, ist der resultirende osmotische Druck derselbe, als wären diese Stoffe nicht da.

Wir gelangen jetet zur Besprechung des dritten Falles: die Zwischenwand lässt den gelösten Stoff und das Lösungsmitel beide, doch nicht in gleichem Maasse, durch.

Passirt ersterer leichter, so hat dies keinen Einfluss auf die Erscheinungen, da in diesem Falle die Gesetze der Diffusion Anwendung finden können; im entgegengesetzten Falle aber, wenn also der gelöste Stoff bei seinem Durchtritt einen gewissen Widerstand zu uberwinden hat, wird er einen diesem Widerstand entsprechenden Druck auf die Scheidewand ausüben. Da sich der Widerstand allen Molectlen entgegenstellt, die bei ihrer Bewe- 
gung die Wand zu passiren suchen, wird derselbe, bezw. der osmotische Druck mit der Zahıl der gelösten Molecüle zunehmen miissen.

Bei einer unvollkommen permeablen Membran entwickelt sich mithin gleichfalls ein Druek, der sich gleich, wie der osmotische Druck im zweiten Falle, erklären lässt; auch jener steigt mit der Concentration der Lösung, erreicht jedoch niemals die Höhe, welche bei impermeablen Membranen zu Stande kommt. Der gelöste Stoff geht durch die Wand mit einer Geschwindigkeit, die bedingt wird durch den der Lösung als solcher eigenen osmotischen Druck und den Widerstand der Membran. Der Durchgang ist langsamer als bei einfacher Diffusion.

Dieser Fall zog anfänglich die meiste Aufmerksamkeit auf sich. Das Durchtreten des Salzes wurde von Graham als Diosmos e bezeichnet, wogegen andere Forscher es Exosmose nannten. Der Uebergang von Wasser wurde durch Graham mit Osmose, von anderer Seite mit Endosmose bezeichnet.

Anfänglich war man der Meinung, dass die Wassermenge, welche mit einem bestimmten Quantum gelösten Stoffes wechselte, eine fuir jeden Stoff constante wäre, und man hat daher den gelösten Stoffen ein "osmotisches Aequivalent" zuerkannt, welches ausdriicken sollte, durch wieviel Wasser die Einheit des gelösten Stoffes ersetzt wurde.

Jolly's Untersuchungen (1849) schienen dies zu bestätigen, und obwohl C. L a d w i g noch in demselben Jahre bewies, dass diese Meinung eine irrige war, und dass sowohl die Membran als die Concentration von Einfluss auf dieses Verhältniss sind, huldigten mehrere Physiologen trotzdem nocb lange dem osmotischen Aequivalent.

In inniger Beziehung zu den Erscheinungen des osmotischen Druckes steht das Sinken des Gefrierpunktes und die Verminderung: des Dampfdruckes durch den in Lösung begriffenen Stoff. Unterziehen wir ersteres einer näheren Betrachtung.

Wird in einer Flüssigkeit der eine oder andere Stoff gelöst, so ist der Gefrierpunkt der Lösung stets niedriger als der des Lösungmittels. Anch hier besteht wieder eine einfache Beziehung zwischen der Menge des gelösten Stoffes and dem Sinken des Gefrierpunktes. Fur nicht zu hohe Concentrationen ist nämlich das 
Sinken des Gefrierpunktes ebenso wie der osmotische Druck proportional der Zahl der gelösten Moleciile.

Wir können nicht umbin, in kurzen Worten noch die Theorie von Arrhenius zu erwähnen, bevor wir za dem physiologischen Theil unserer Arbeit ibergehen.

Eine Anzahl von Salzen zeigt in wässeriger Lösung eine beträchtlichere Gefrierpunktserniedrigung bezw. einen höheren osmotisehen Druck, als van t' Hoff's Theorie zu erfordern scheint. Der genannte Forscher erklärt diese Abweichung, indem er Bezug nimmt auf eine Hypothese, zu der Arrhenius bereits frither gelangt war, nämlich, dass in Wasser gelöste Salze eine totale oder partielle Zersetzung erleiden, darin bestehend, dass das Metall sich vom Säureradical trennt. Die Spaltungsproducte nennt $A$. Jonen, weil sie seiner Vorstellung nach mit positiver, resp. negativer Elektrizität bebaftet sind, und die Erscheinung hydrolytische Dissociation.

Mit Bezug auf den osmotischen Druck wird dieselbe den gleichen Effect haben, als wäre eine grössere Zahl von Moleeülen in der Lösung vorhanden [.,doppelt bombardirende Molecüle" - van t' Hoff]; der osmotische Druck wird demgemäss höher, die Gefrierpunktserniedrigung und die Dampfdruckverminderung werden beträchtlicher sein, als der ursprünglichen Anzahl von Moleciilen entspricht, und so sind denn auch in Wirklicbkeit die Abweichungen dieser drei Grössen einander proportional.

Die hydrolytische Dissociation nimmt mit dem Grade der Verdünung $z \mathfrak{u}$, jedoch bei verschiedenen Salzen nicht im gleichen Maasse. In den zu physiologisehen Zwecken gebräuchlichen Concentrationen sind Salze vom Typus des Chlornatriums und des Chlorcalciums in wässeriger Lösung als fast vollständig dissociirt anzusehen. Nicht so weitgehend ist die Dissociation bei Magnesiumsulfat und dergleichen Salzen, die aus einem zweiwerthigen Metall und einer zweibasischen Säure zusammengesetzt sind.

Metallfreie organische Verbindungen sind der hydrolytischen Dissociation meistens nicht oder nur in geringem Maasse unterworfen.

I.

Nach den ersten Entdeckungen auf dem Gebiete der Osmose und Diosmose hat man sofort versucht, diese auf den Austausch 
der Flüssigkeiten in Organen und Zellen anzuwenden. Eine Uebersicht dieser Bestrebungen zu geben, würde mich za weit führen, und ich beschränke mich daher anf die späteren Untersuchungen, soweit diese in mehr directer Bezichung zu meinem Thema stehen.

Bringen wir eine lebende Zelle in eine beliebige wässerige Lösung, so sind, wenn man in Anrechnung zieht, dass Zellen für Wasser permeabel sind, wieder drei Möglichkeiten gegeben, nämlich: 1. der gelöste Stoff geht ebenso leicht, wie Wasser, durch die Scheidewand (Diffusion), 2. er vermag dieselbe gar nicht zu passiren (Osmose), und 3. er geht durch die Seheidewand, aber nicht so leicht wie Wasser (Endosmose). Wollen wir nun das Verhalten der Zelle gegenüber verschiedenen Lösungen näher studiren, so ist vor allen Dingen nöthig festzustellen, mit welchem der drei angeführten Fälle wir es jedesmal zu thun haben.

Einer der ersten, der sich damit beschäftigte, war H. de Vries ${ }^{1}$ ). Er untersuchte das Verhalten gewisser Pflanzenzellen in versehiedenen Lösungen und fand, dass sie viele Stoffe nicht eindringen lassen, während auch umgekehrt viele der im Zellsaft gelösten Stoffe, solange die Zelle lebt, nicht aus dieser heraustreten. Bei seinen weiteren Studien über diesen Gegenstand ${ }^{2}$ ) ging de Vries aus von der schon bekannten Thatsache, dass, wenn man Lösungen unsehädlicher Stoffe auf lebendige Pflanzenzellen einwirken lässt, das Protoplasma sich von der Zellwand zuriickzieht. Diese Erscheinung, Plasmolyse genannt, beruht darauf, dass die Lösung dem Zellinhalt Wasser entzieht. Sucht man nun für dieselben Zellen diejenige Concentration der Lösungen verschiedener Stoffe aus, welche grade den Anfang der Plasmolyse bervorrufen, so entziehen diese den Zellen offenbar mit derselben Kraft Wasser, d. h. sie sind isotonisch. Er fand nun, das diese Concentrationen, wenn man sie nicht nach Gewichtsprocenten, sondern nach Molecülen berechnet, sich zu einander nahezu verhalten wie ganze Zahlem, seine sogenannten ,isotonischen Coefficienten“. Fïr die Glieder einer nämlichen chemischen Gruppe haben diese nahezu denselben Werth.

1) Sur l'imperméabilité du protoplasma des betteraves rouges, Archives Néerlandaises 1871 , Tme 6, p. 121.

2) Ueber die Anziehung zwischen gelösten Stoffon und Wasser in verdünnten Lösungen, Berichte und Mittheilungen der königl. Academie der Wissensch. in Amsterdam, II 9, S. 312. 
Weitere Untersuchungen iiber das Durchdringen gelöster Stofle dureh die Plasmamembran (Hyaloplasma) und die Vacuolenwand unternahm Janse ${ }^{1}$ ). Er fand nicht allein, dass manche Stoffe das Hyaloplasma passiren und in die Vacuolen gelangen können, sondern auch, dass deren einige, solarge die Zelle am Leben bleibt, nicht wieder herausgehen.

So war z. B. bei Zellen von Spirogyra nitida, nach einem Aufenthalt von 24 Stunden in einer verdiunten Salpeterlösung, eine dentlich wahrnchmbare Quantitiit dieses Salzes in die Vacuolen eingedrungen. Wurden jedoch darnach die Zellen während einer Zeitdauer von 70-78 Tagen in eine isotonische Kochsalzlösung. gebracht, so war in der Vacuole der Salpeter noeb gleich deutlich nachzuweisen wie am ersten Tage. Deshalb spricht Janse von Intra- und Extra-Permeabilität.

Ueber die Permeabilität thierischer Zellen fand ich bis jetzt nur spärliche Aufzeichnungen. Schon lange ist bekannt, dass mehrere Salze sehr schnell aufgenommen werden können und in die Secrete übergehen, wie z. B. für Jodkalium bewiesen wurde. Hicrbei blieb es jedoch zweifelhaft, ob wir es mit einer einfachen Diffusion oder mit einem Resorptions- (resp. Secretions-) Vorgang, an dem die Zellen einen thätigen Antheil nehmen, zu thun hatten.

Hamburger's ${ }^{2}$ ) Untersuchungen ïber die Permeabilität der rothen Blutkörperchen haben für mich wenig Ueberzeugendes.

Er vermischte eine bestimmte Quantität Blut mit einer gewissen Menge einer mit dem Serum isotonischen Salpeterlösung und bestimmte alsdann den Chlorgehalt 1 . der durch Centrifugiren erhaltenen serösen Flüssigkeit, 2. des unverdiunnten Blutserums. Aus den auf diese Weise erhaltenen Werthen berechnete er, wieviel Chlor(-Natrium?) durch die Blutkörperehen an die Lösung abgegeben war, wobei er annahm, dass das Volumverhältniss der Blutkörperchen zum Plasma beim Pferde wie 40:60 sei, eine Annahme, aus frïheren Bestimmungen abgêleitet, bei denen aber der

1) Die Permeabilität des Protoplasma, Ber. und Mitth. der königl. Academie der Wissensch. in Amsterdam. III 4. S. 332.

2) Ha mburger, Over de permeabiliteit der roode bloedlichaampjes in verhand mot de isotonische coefficienten. Berichte und Mitheilungen der Kön. Acad. d. Wissensch. in Amsterdam, 1890. 
Thatsache, dass starke Salzlösungen das Volumen der rothen Blutzellen vermindern, keine Rechnung getragen war.

Dass man wirklich Grund hat, an der Richtigkeit der Untersuchungen von Hamburger zu zweifeln, wird dentlich erscheinen, sobald man seine Angaben ein wenig umrechnet.

So finden wir in Versuch 2 (S. 19):

$20 \mathrm{ccm}$ Kalbsblut werden vermischt mit $40 \mathrm{ccm}$ einer $\mathrm{NaNO}_{3}$-Lösung von $1 \frac{1}{2} \%$ (isotonisch).

Vom unvermischtem Serum fordern:

$12 \mathrm{~cm} 12,46 \mathrm{ccm} \mathrm{1/10} \mathrm{norm.} \mathrm{Silbernitratlösung.}$

Von dem mit Salpeterlösung verdïnnten Serum entsprechen $20 \mathrm{ecm}$ $8,62 \mathrm{~cm} 1 / 10$ norm. Sibernitratlösung. $20 \mathrm{ccm}$ Blut fassen $12 \mathrm{ccm}$ Serum. Im Ganzen haben wir also $52 \mathrm{ccm}$ seröser Flüssigkeit und $8 \mathrm{~cm}$ rother Plutkörperchen. 52 ccrn seröser Fliissigkeit fordern $\frac{52}{20} \times 8,62=$

$$
22,41 \mathrm{ccm} 1 / 10 \text { norm. Silherlösung. }
$$

$12 \mathrm{~cm}$ Serum fordern $12,46, "$, $8 \mathrm{ccm}$ Blutkörperchen geben also eine Quantität Chlor ab, welche übereinkommt mit $8 \mathrm{ccm}$ Serum aber enthalten eine Quantität Chlor, welche übereinstimmt mit $\frac{8}{12} \times 12,46=$

$$
9,95
$$

Die Blutzellen bätten demnach eine Quantität Chlor abgegeben, die grösser ist als der Chlorgebalt des Serums! Dem ist entgegenzuhalten, dass der Chlorgebalt der rothen Blutzellen geringer ist als der des Serums.

\section{Versnch 5.}

$20 \mathrm{ccm}$ Pferdeblut werden gemischt mit $40 \mathrm{~cm}$ Serum und $10 \mathrm{~cm}$ einer isotonischen Kochsalzlösung.

$12 \mathrm{com}$ Serum erfordern . . . 12,24 ccm einer 1/10 norm. Silbernitratlösung. 10 , NaCl-Lösung erfordern 18,57 " " " " , 20 "des verdünnten Serums 16,77, " , , " ,

Wir haben $12 \mathrm{ccm}$ Serum vom Blut, dazu $40 \mathrm{~cm}$ Serum, zusammen $52 \mathrm{ccm}$ Serum;

diese erfordern $\frac{52}{12} \times 12,24 \mathrm{ccm}=53,04 \mathrm{ccm} \mathrm{1/10} \mathrm{norm.} \mathrm{Silbernitratlösung.}$

$10 \mathrm{ccm}$ NaCl-Lösung verlangen $18,57, \quad, \quad$, Summe $71,61 \mathrm{cem} 1 / 10$ norm. Silbernitratiosung. 
Die Menge des verdünnten Serums beträgt $62 \mathrm{ccm}$ und erfordert somit $\frac{62}{20} \times 16,77 \mathrm{ccm}=. . . \quad .51,99 \mathrm{~cm} \mathrm{1/10}$ norm. Silbernitratlösung.

Die von $8 \mathrm{~cm}$ Blutkörperchen aufgenommene Chlormenge entspricht mithin: . . . . . . . . $19,62 \mathrm{ccm} 1 / 10$ norm. Silbernitratlösung.

Das gleiche Volum einer isotonischen $\mathrm{NaCl}$ - Lösung entspricht aber $\frac{8}{10} \times 18,57 \mathrm{ccm}=$. . . . . 14,86, , " " "

Die Blutkïrperchen miissten folglich mehr Chlor aufgenommen haben, als dem Cblorgehalt einer isotonischen Kochsalzlösung entspricht!

Nach diesen Berechnungen halte ich es für überfliissig, noch näher auf Hamburger's Schlussfolgerungen einzugehen.

Uebrigens war es, nach Hamburger's eigener Beobachtung, dass eine Kochsalzlösung der wasseranziehenden Kraft der Blutkörperchen das Gleichgewicht zu halten vermag. ${ }^{1}$, von vornherein recht unwahrscheinlich, dass dieses Salz leicht in dieselben eindringen könnte. Denn naturgemäss vermögen nur solche Stoffe eine isotonische Lösung zu geben, für welche die Blutzellen nicht permeabel sind.

Weiterhin wurde von Hamburger die osmotische Wirkung verschiedener Lösungen auf rothe Blutzellen in zweierlei Weise untersucht, indem er erstens bestimmte, bis zu welcher Concentration ein Stoff gelöst vorhauden sein muss, um den Farbstoff nicht aus den Zellen austreten zu lassen ${ }^{2}$ ); zweitens mikroskopisch untersuchte, welchen Veränderungen die rothen Blutzellen in verschieden starken Lösungen unterworfen sind ${ }^{3}$ ).

Letztere Methode erscheint mir weniger gut, und die Interpretation der durch Hamburger wahrgenommenen Erscheinungen ist sicherlich nicht richtig.

Wenn in einer Kochsalzlösung von $0,64 \%$ die Blutkörperchen des Frosches unverändert bleiben, so kann, bringt man diese in eine Seite 22.

1) Untersuch. a. d. physiol. Laboratorium in Utrecht, 3e Folge, T. 9,

2) Hamburger, Ebendaselbst Theil 10, Seite 35.

3) Ilamburger, Archiv für Anatomie n. Physiologie. 1888. 
Lösung von nur 0,21\%, sehwerlich von Plasmolyse die Rede sein. Dieser Vorgang kann nur in einer hyperisotonischen Flissigkeit stattfinden, jedoch nicht in hypisotonischen Flüssigkeiten, weil in diesen das Protoplasma durch Wasseranfnahme nur noch stärker gegen die Zellwand gedrickt würde.

Da wir iibrigens bei den rothen Blutzellen kaum eine Zellhülle, auf keinen Fall aber eine wenig biegsame Zellwand annehmen dürfen, so werden Erscheinungen von Plasmolyse ${ }^{1}$ ) hierbei wohl stets problematisch bleiben.

Mehr Anspruch auf Anerkennung kann die andere Methode erheben, obwohl auch sie nicht ganz einwandfrei erscheint.

Sie besteht im Folgenden: Vom Serum des zu untersuchenden Blutes macht man mehrere Verdünnnngen in bekanntem Mischungsverhältniss, stellt daneben eine Reihe von Lösungen in verschiedener Stärke des zu untersuchenden Salzes, und bringt in jede dieser Flüssigkeiten eine kleine Menge Blut oder rothe Blutzellen. Nach einiger Zeit - H a m b u r g e r giebt 24-48 Stunden an - kann man wahrnehmen, bei welchen Verdiunnungen des Serums und bei welcher Concentration der Salzlösung die Blutkörperchen zu Boden gesunken sind, ohne Farbstoff an die Flüssigkeit abzugeben, und in welchen Lösungen letzteres wohl der Fall ist.

Aus der Grenzeoncentratiou der Salzlösung und der Grenzverdünnnng des Serums berechnen wir dann die isotonische Salzlösung, indem wir erstere multipliziren mit der Zahl, welche das Mischungsverhältniss des Serums angiebt.

Z. B. Pferdeblut 1): Der Austritt des Farbstoffes macht den Anfang in einer Lösung von $0,65 \% \mathrm{NaCl}$; ebenso in einer Mischung von $5 \mathrm{ccm}$ Serum und $2,6 \mathrm{ccm}$ Wasser. Die isotonische Kochsalzlösung beträgt also $\frac{2,6+5,0}{5,0}$ $\times 0,65 \%=0,99 \%$.

Die Ergebnisse dieser Untersuchungen stehen in Einklang mit den Resultaten und Ziffern, welche de Vries bei seinen plasmolytischen Studien erhielt, weshalb denselben ein nicht geringer Werth beigelegt werden muss. Dies darf uns jedoch nicht davon abhalten, uns nähere Rechenschaft zu geben iber dasjenige, was wir eigentlich bestimmen.

1) Recucil d. travaux chim. r. Pays-Bas, T. 13, No. 2. 
Das Austreten von Hämoglobin aus den Blutzellen ist eine noch nicht geniigend erklärte Erscheinung. Indess, die verschiedenen Ursachen, die es hervorrufen (hohe Temperaturen, wiederholtes Erfrieren und Aufthanen, Protoplasmagifte, starke Inductionsschläge u. s. w.), weisen mit Bestimmtheit darauf hin, dass es, wenn nicht immer eine Erscheinung des Absterbens, dann zum mindesten ein Zeichen tiefgehender Veränderungen der Blutkörperchen ist. Einen pathologischen Vorgang als Basis für plysiologische Untersuchungen zu nehmen, scheint mir aber stets einigermaassen bedenklich, voryighlich wo es sich um quantitative Bestimmungen handelt.

Meine Erfahrung über die Brauchbarkeit der H a m b u r'g e r'schen Methode ist wenig zufriedenstellend; namentlich erwiesen sich die Resultate abhängig von der Zeitdauer, nach welcher die Beobachtungen iiber den Austritt des Blutfarbstoffes angestelit wurden. Ich möchte mir das folgendermaassen erklären: werden Blutkörperchen in ein fremdes Medium ubertragen, so ist es mindestens zweifelhaft, ob sie darin ebenso lange intact sich erhalten werden, als in ilı'em natiurlichen Element (Bakterienwirkung ausgeschlossen). Die Voraussetzung, auf welcher die gesagte Methode beruht, dass nämlich jene verdiunte Salzlösung, in welcher die Blutzellen nach längerer Zeit eben im Begriff sind ihren Farbstoff alszugeben, mit dem entsprechend verdünnten Serum isotoniseh sei, erscheint demnach nicht unanfechtbar. Vielmehr wäre anzunehmen, dass der Hämoglobinaustritt in die Lösung bei einer weniger erniedrigten, osmotischen spannung, als in das Serum, stattfinden, und dass auch die Dauer des Versuchs auf diese Differenz von Einfluss sein wird.

Benutzen wir bei den in Rede stehenden Versuchen vergleichsweise Lösungen verschiedener Stoffe, die für die Blutzellen gleich indifferent sind, so finden wir Werthe, die allein dureh die physikalischen Eigenschaften dieser Stoffe bedingt werden und folglich genügend unter einander und mit den Ergebnissen von nach anderen Methoden angestellten Untersuchungen übereinstimmen können, ohne jedoch die physikalische Constante des Sermms auszudrücken.

Noch weniger einverstanden muss ich mich erklären mit der Weise, in welcher Ha mb u $\mathrm{rg}$ er in seiner Arbeit "Ueber die Regulirung der Blutbestandtheile bei künstlicher Plethora, Hy- 
drämie und Anämie ${ }^{\text {1 }}{ }^{1}$ ) die osmotische Spannung (bezw. Wasseranziehungskraft) der Blutkörperchon untersucht.

Wird, dureh Einspritzung einer hyperisotonischen Salzlösung in die Blutbahn irgend eines Thieres, den Blutkörperehen Wasser entzogen und ihre osmotische Spannung demgemäss crlöht; so ist das kein Grund, warum, bei Prüfung nach $\mathrm{Hamburger}$ 's Metbode, ihr Verhalten gegenüber verdiunnten, stark hypisotonischen Lösungen sich merklich geändert zu haben braucht. Wenn alșo Blutkörperehen, aus versehiedenen, dem Thiere vor und nach der Einspritzung entnommenen, Blutproben stammend, nacb Uebertragung in verdünnte Salzlösungen den Farbstoff bei gleich niedrigem os: motischen Druck abzugeben beginnen, so beweist das nicht, wie $\mathrm{Ha} \mathrm{m} \mathrm{bu} \mathrm{rger} \mathrm{annimmt,} \mathrm{dass} \mathrm{sie} \mathrm{gleiche} \mathrm{Wasseranziehungskraft}$ besassen. Dessen Schlussfolgerung, dass unter verschiedenen Umstïnden die Blutkörperchen bestrebt sind, ibre Wasscranziehungs. kraft constant $z$ erbalten, ist demnach dureh seine Untersuchungen nicht genuigend motivirt.

Auf $\mathrm{Ha} \mathrm{mburger}$ 's spätere Veröffentlichungen werde ich gelegentlich noch zurïckkommen und mich jetzt beschränken anf die Bemerkung, dass mir dessen Standpunkt in Anbetracht der osmotischen Eigenschaften der rothen Blutkörperehen niemals vollständig klar geworden ist, da er letzteren in einem Falle leiehtes Aufnehmen und Abgeben von Wasser zumuthet ${ }^{2}$ ), im anderen Falle behauptet, ihre Wasseranziehnngskraft sei eine constante.

In der ibbrigen, mir zur Verfïgung stehenden Litteratur habe ich wenig iaber die Permeabilitait der rothen Blutzellen gefunden, weshalb ich jetzt zur Besprechung meiner eigenen Beobachtungen iiber diesen Gegenstand uibergehen werde.

Einige Autoren sprechen von einer "schtitzenden Thätigkeit", die das Kochsalz (sowie einzelne andere Stoffe) auf die Zellen ausüben soll, indem es viele jener Stoffe, die in destillirtem Wasser gelöst, die Blutkörperehen und andere Zellen vernichten, daran verhindert, ihren nachtheiligen Einfluss auszuïben.

Der Ausdruck ,schützende Thätigkeit" ist jedoch nur eine

1) Berichte u. Mittheilungen der Königl. Acad, d. Wissensch, in Amsterdam. 3. Folge, VII. S. 413.

2) Ueber die durch Salz- und Rohrzuckerlösungen bewirkten Veränderungen der Blutkörperchen. Archiv f. Anat. und Physiol, 1887. 
Umschreibung, keine Erklärung einer wahrgenommenen Thatsache, weshalb ich mich zuerst hiermit beschäftigt habe.

Es schien mir logiseh, die destruirende Wirkung des destillirten Wassers zum Ausgangspunkt zu wählen. Da wir nicht annehmen diurfen, dass Wasser, welches den grössten Bestandtheil aller lebenden Wesen ausmacht, als chemisches Agens einen nach. theiligen Einfluss auf die Zellen ausiibt, müssen wir die Wirkung des destillirten Wassers als eine rein physikalisehe betrachten. Bringen wir eine lebende Zelle in destillirtes Wasser, so habcn wir, weil die gelösten Stoffe des Zelleninhaltes nicht leicht oder iiberhaupt nieht durch die Plasmamembran ${ }^{1}$ ) dringen, Wasser dagegen wohl, eine Lösung, welche durch eine für das Menstrunm leicht, fiir den gelösten Stoff beinahe oder überhaupt nicht durehdringbare Wand vom Lösungsmittel geschieden ist. Innerbalb der Zelle wird sich demnach ein osmotischer Druck offenbaren, der abhängig ist von der molecnlaren Menge des gelösten Stoffes, in Verbindung mit seiner Theilung in Jonen. Dieser Druck wird bestrebt sein, die Zelle durch Wasseraufnahme auszudehnen. Die Kraft, mit welcher solches geschieht, ist eine bedentende ${ }^{2}$ ). Die Ausdehnng der Zellenwand wird fortdauern, bis ihre elastische Spannung mit dem osmotischen Drucke im Gleichgewichte steht ${ }^{3}$, oder bis die Wand, sei es durch starke Spannung oder durch Zerreissen, für die gelösten Stoffe durchgängig geworden ist. An Beispielen, dass durch die Wirkung des Wassers Zellen zerstört sind, fehlt es denn auch nicht.

An den rothen Blutzellen ist die destruirende Wirkung des destillirten Wassers daraus ersichtlich, dass sie den Farbstoff verlieren und zu Kügelchen, deren Brechungsexponent von dem des Wassers nur wenig verschieden ist, anschwellen.

Bringen wir hingegen die Blutkörperchen in eine geeignete Salzlösung, so sehen wir jene Veränderungen nicht auftreten; der

1) Unter Plasmamembran verstehe ich hier im Allgemeinen die Grenzschicht, gleichgültig ob diese dieselbe oder eine andere Structur als das übrige Protoplasma zeigt, weil dies für die osmotischen Erscheinungen nicht von Wichtigkeit ist.

2) Eine Salpeterlösung von $1 \%$ besitzt z. B. bereits einen osmotischen Druck von mehr als 2 Atmosphären (Pfeffer).

3) Wolcher natürlich durch Verdünnung des Zellinhalts abnimmt. 
osmotische Druck des Zellensaftes und jener der Lösung halten einander das Gleichgewicht: die Lösung ist isotoniseh.

Von einigen Stoffen aber, wie Harnstoff, Chlorammonium u.s. w., kommt keine Lösung in Wasser zu Stande, worin das Verbalten der Blutkörperchen das gleiche ist wie in einer isotonischen Kochsalzlösung. Wie concentrirt eine Harnstofflösung auch sein mag, immer findet darin eine Quellung der rothen Blutkörperchen unter Hämoglobinaustritt statt.

Setzen wir aber zu der Harnstofflösung soviel Kochsalz hinzu, dass der Salzgehalt mit dem der oben erwähnten isotonischen Lösung übereinstimmt, so bleiben die Blutkörperchen anverändert. Werden weiter von einer isotonischen Kochsalzlösung zwei Reihen von Verdünnungen gemacht, die eine mit destillirtem Wasser, die andere mit einer Harnstofflösung, so sehen wir, wie der Farbstoff des Blutes in beiden Reihen bei demselben Grade der Verdiinnung auszutreten beginnt.

Bei diesen Untersuchungen kann das Kochsalz durch andere Stoffe (andere Metallsalze, Zucker u. s. w.), ohne dass eine Veränderung des Resultates eintritt, ersetzt werden. Wir werden also zn der Annahme gezwungen, dass dem Kochsalze keine specifische schuitzende Thätigkeit zukommt, und dass in Lösungen der Harnstoff den rothen Blutzellen gegenuiber sich verhält, als wäre er nicht vorhanden. Der Harnstoff ibt somit nicht als ein chemisches Agens etwa eine specifische Giftwirkung anf die rothen Blutzellen aus, sondern die schädliche Einwirkung einer reinen Harnstofflösung entspricht der des destillirten Wassers. Diese Thatsache lässt sich physikalisch leicht erklären. Wenn der Harnstoff ungehindert durch die Zellwand diffundirt, wird seine Lösung der Zelle gegenüber keinen osmotischen Druck entwickeln. Die Harnstofflösung kann also dem osmotischen Druck des Zellinhaltes niemals das Gleichgewicht halten, und letzterer wird einer Harnstofflösung gegeniiber genau dieselbe deletere Wirkung anf die Zelle ausüben wie beim destillirten Wasser.

Das Eindringen des Harnstoffs in die rothen Blutkörperchen wurde von mir auf chemischem Wege naohgewiesen. Defibrinirtes Hühnerblut wurde centrifngirt, das Serum abgehoben und durch eine Lösung von $10 \%$ Harnstoff und 0,88 bis $0,9 \% \mathrm{NaCl}$ in Wasser ersetzt. Hieranf wurde die Senkungssehicht in die Fliissigkeit vertheilt und nach kurzer Zeit wieder centrifugirt. Der Harnstoff- 
gehalt der serösen Flïssigkeit suwie des Sediments (das aus rothen Blutkörperchen nnd einer kleinen Quantität seröser Zwischenflisssigkeit besteht) wurde jetzt mittelst Bromlauge bestimmt und fur beide nahezu gleich gefunden ${ }^{1}$ ). Da nun keine Griinde vorhanden sind, welche uns zu der Annahme berechtigen, dass die seröse Flissigkeit zwischen den Erythrocyten bedeutend mehr Harnstoff enthalte als die obenstelende Flïssigkeit, muissen wir schliessen, dass der Harnstoff sich gleichmässig iiber Blutkörperchen und seröse Flisssigkeit vertheilt bat ${ }^{2}$ ).

Auf dieselbe Weise wurde das Eindringen von Anmoniumeblorid in die Blutkörperehen constatirt; jedoch dürfen liervon nur geringe Mengen Verwendung finden, weil bereits bei einem Concentrationsgrade von $1,5 \%$ die Blutkörperchen zu einer schleimigen Masse - auch wenn Kochsalz in erforderlicher Menge vorhanden ist - zusammenfliessen.

Da verhältnissmässig nur wenige Stoffe quantitativ sich leicht im Blut bestimmen lassen, habe ich für die iibrigen Stoffe nicht, wie für Harnstoff and Chlorammonium, die gleichmässige Vertheilung über fliissige und körperliche Blutbestandtheile nachzuweisen versucht, sondern habe angenommen, dass ein Stoff durchdringt, wenn er in wässeriger Lösung die Blutkörperchen schnell auföst, während er in einer isotonischen Kochsalzlösung nicht oder erst nach längerer Zeit den Farbstoff austreten lässt.

Tritt in der etwa isotonisehen wässerigen Lösung eines Stoffes der Blutfarbstoff nicht unverweilt aus, sondern gar nicht oder erst

1) Da bei diesen Bestimmungen des Stickstoffes, ausgeführt mit dem kleinen Apparat von J. F. Eykman, nur kleine Mengen der zu untersuchenden Mischungen Verwendung fanden, ist die Genauigkeit der Resultate nicht so gross, dass der Einfluss des nicht als aufgelöst zu betrachtenden Theiles der rothen Blutkörperchen sich deutlich geltend machen kann (vgl. S. 111).

Genauere Untersuchungen nach der Kjeldahl'schen Methode der Stickstoffbestimmung habe ich aus Mangel an Zeit einstellen müssen.

2) Die bekannte Langsamkeit der Diffusion im Gegensatz zu dem schnellen Reagiren der Blutkörperchen auf destillirtes Wasser und auf Lösungen durchdringender Salze bildet keine Schwierigkeit mit Bezug anf die hier oben gegebene Erklärung, weil die Dimensionen der Zellen sehr klein sind und der von allen Seiten eindringende Stoff nur die Hälfte der kleinsten Dimension zurückzulegen hat. 
nach längerer Zeit und hat Zusatz einer aquivalenten Kuchsalznenge auf diese Zeitdauer keinen merklichen Einfluss, so ist anzunehmen, dass der Stoff nicht in die rothen Blutzellen diffundirt.

Soweit unsere Untersuchungen sich erstrecken, sind die rothen Blutkörperchen permeabel befunden fiü nachfolgende chemische Verbindungen:

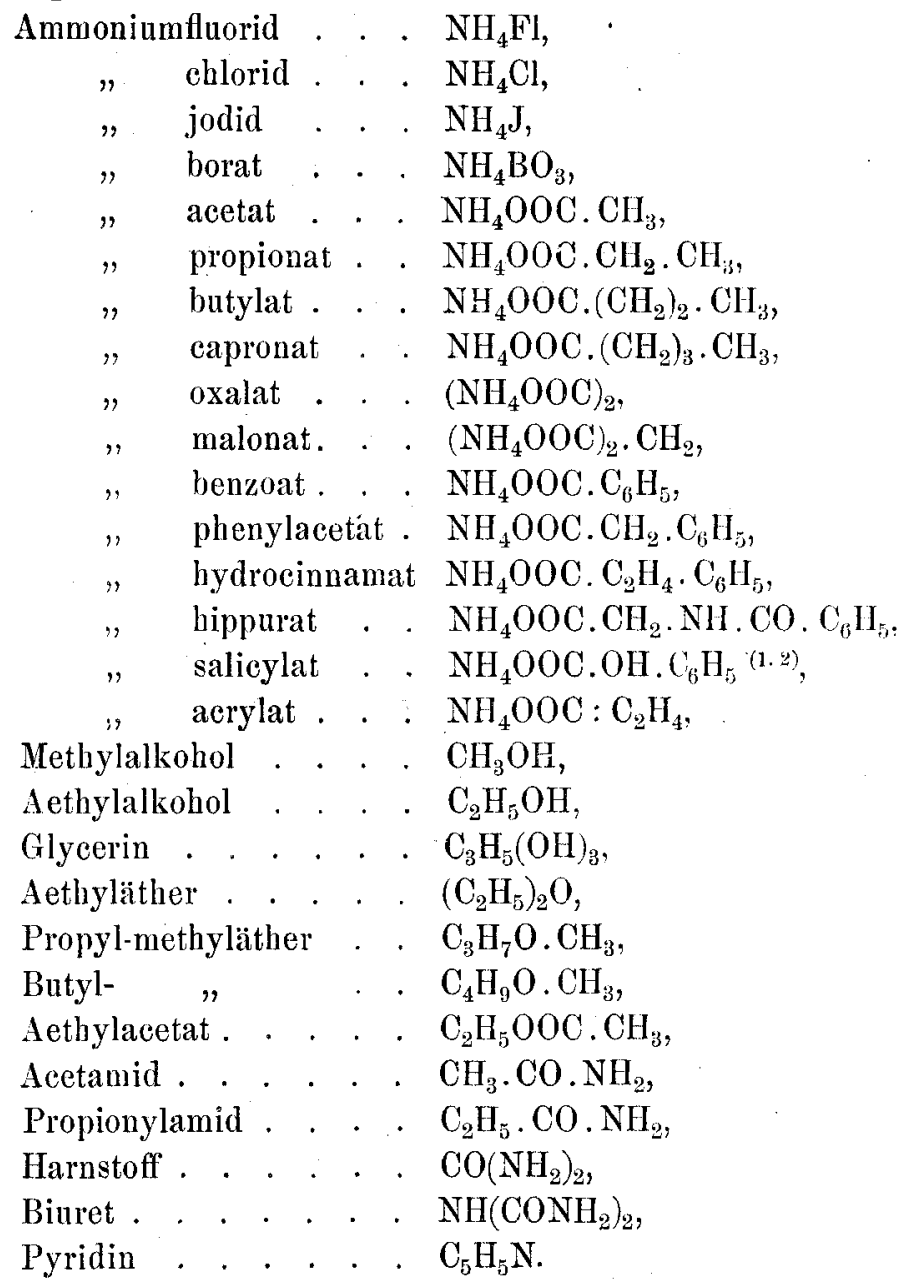

Nicht durchtretende Verbindungen sind:

Ammoniumnitrat . : $\mathrm{NH}_{4} \mathrm{NO}_{3}$,

$\begin{array}{lll}" & \text { sulfat . } ~ & \left(\mathrm{NH}_{4}\right)_{2} \mathrm{SO}_{4} \\ " & \text { thiocyanat } & \mathrm{NH}_{4} \mathrm{CyS}, \\ " & \text { phosphat } . & \left(\mathrm{NH}_{4}\right)_{3} \mathrm{PO}_{4},\end{array}$


Lithiumchlorid . . . $\mathrm{LiCl}$,

Natrium " . . . . NaCl,

" bromid . . . . $\mathrm{NaBr}$,

$"$ fluorid . . . NaFl,

" sulfat . . . . $\mathrm{Na}_{2} \mathrm{SO}_{4}$

$"$ nitrat . . . $\mathrm{NaNO}_{3}$,

Kaliumehlorid . . . $\mathrm{KCl}$,

$"$ bromid . . . . $\mathrm{KBr}$,

$"$ jodid . . . . KJ,

Calciumchlorid . . . $\mathrm{CaCl}_{2}$,

Strontium , . . . . $\mathrm{SrCl}_{2}$,

Bariumchlorid . . . $\mathrm{BaCl}_{2}$,

Magnesinmchlorid . . $\mathrm{MgCl}_{2}$,

Ammoniumferrocyanid . $\left(\mathrm{NH}_{4}\right)_{4} \mathrm{FeCy}_{6}$,

$"$ ferri $"$. $\left(\mathrm{NH}_{4}\right)_{6} \mathrm{Fe}_{2} \mathrm{Cy}_{12}$,

" lactat. . . $\mathrm{CH}_{3}$. $\mathrm{CHOH} . \mathrm{COONH}{ }_{4}$,

$" \quad$ tartrat. . . $(\mathrm{CHOH})_{2} \cdot\left(\mathrm{COONH}_{4}\right)_{2}$,

$"$ succinat . . $\left(\mathrm{CH}_{2}, \mathrm{COONH}\right)_{4}$,

$" \quad$ citrat . . . $\left(\mathrm{CH}_{2} \cdot \mathrm{COH} \cdot \mathrm{CH}_{2}\right)(\mathrm{COONH})_{2}$,

$"$ malat. . . CHOH. $\mathrm{CH}_{2} \cdot\left(\mathrm{COONH}_{4}\right)_{2}$,

Glycocoll . . . . $\mathrm{NH}_{2} \cdot \mathrm{CH}_{2} \cdot \mathrm{COOH}$,

Asparagin (Amiddbrnsteinsäure) $\mathrm{CONH}_{2} \cdot \mathrm{CH}_{2} \cdot \mathrm{CH} \cdot \mathrm{NH}_{2} \cdot \mathrm{COOH}$,

$"$ ammoniak. $\mathrm{CONH}_{2} \cdot \mathrm{CH}_{2} \cdot \mathrm{CHNH}_{2} \cdot \mathrm{COONH}_{4}$,

Natriumacetat . . . $\mathrm{CH}_{3}$. $\mathrm{COONa}$,

$n$ propionat. $\mathrm{C}_{2} \mathrm{H}_{5} \cdot \mathrm{COONa}$,

$"$ malonat . $\mathrm{CH}_{2}(\mathrm{COONa})_{2}$,

, phenylacetat $\mathrm{C}_{6} \mathrm{H}_{5} . \mathrm{CH}_{3} . \mathrm{COONa}$,

$"$ oxalat . ( $(\mathrm{COONa})_{2}$,

$"$ hippurat. . $\mathrm{C}_{6} \mathrm{H}_{5} \cdot \mathrm{CO} \cdot \mathrm{NH} \cdot \mathrm{CH}_{2} \cdot \mathrm{COONa}$,

Dextrose . . . . $\mathrm{C}_{6} \mathrm{H}_{12} \mathrm{O}_{6}$,

Mannit . . . . . $\mathrm{C}_{6} \mathrm{H}_{14} \mathrm{O}_{6}$,

Inosit . . . . . $\mathrm{C}_{6} \mathrm{H}_{12} \mathrm{O}_{6}$,

Saccharose . . . . . $\mathrm{C}_{12} \mathrm{H}_{22} \mathrm{O}_{11}$,

Lactose . . . . . . $\mathrm{C}_{12} \mathrm{H}_{22} \mathrm{O}_{11}$.

Aus Obenstehendem ergeben sich zunächst folgende Regeln:

1. Salze mit einem Metall -Jon treten nicht durch.

2. Weil die Ammoniumsalze der Halogene und einiger Säuren wohl, die von anderen Säuren dahingegen nicht durchgehen, und andrerseits keine Verbindungen von Metallen mit Halogenen 
oder durchtretenden Säuren die Blutkörperchen durchdringen können, so midssen wir schliessen, dass eine Verbindung nicht durchdringt, wenn auch nur eins ihrer Jonen nicht durehdringen kann.

Der Unstand, dass ein durchdringendes Jon durch ein nicht durchdringendes am Eindringen in die Blutkörperchen gehindert wird, ist ein neuer Beweis für die innige Weclsselbeziehung zwischen den Jonen einer chemischen Verbindung.

Stoffe, welche irgendwie schädigend auf die Blutkörperchen einwirken, eignen sich zu diesen Versuchen nicht.

Soll das Verhalten einer Säure untersucht werden, so bindet man sie, und zwar mit Ammoniak, nicht mit einem Metall, weil letzteres schon an und für sich das Durchdringen hindert. Basen mitssen mit einem Halogen oder einer durchdringenden Sïture verbunden werden.

Die zu einer Gruppe gehörenden organischen Verbindungen zeigen meistens das gleiche Verhalten. So sind z. B. die einwertigen Alkohole, die Fettsätren, die .lether pernieante, die (lïslichen) Kohlenhydrate, und iiberhaupt viele optisch active orga= nische Verbindungen, nichtpermeante Stoffe.

In eine Fettsäure substituirt, hebt der Benzolkern dic Durchdringungsfälighkeit nicht anf (vergl. Benzoësäure und Hippursäure).

Die Amide der durchdringenden Sänren gehen dureb, die Amidosäuren, wenigstens Amido-Essigsäure (das abweichende Verhalten der Amido-Bernsteinsäurc beweist nichts, weil die Säure selbst nichtpermeant ist) nicht. Der permeante Harnstoff wïrde anch danach vielmehr als Carbonyldiamid, denn, wie Einige wollen, als Amidoformamid aufzufassen sein.

Ich erachte es von Wichtigkeit, auch von anderen Zellen die Permeabilität für verschiedene Stoffe zu untersuchen, weil hier, in Anbetracht der oben vorgetragenen Anschaungen über 0 smose, ein nener Standpunkt einzunehmen wäre gegeniiber untersehiedlichen physiologischen und pharmacodynamischen Erklärungen.

So wïrde z. B. die Thatsache, dass Salze, wie Glaubersalz, englisches Salz, Magnesiumcitrat, eine purgirende Wirkung entfalten, Kochsalz, Chlorkalium u. s. w. dagegen nicht, leicht zu erklären sein, wenn erstere ïberhaupt nicht oder nur mïhevoll, die letzteren leicht durch das Darmepithelium diffundiren, ein Sachverhalt, der sehr annehmbar erscheint, weil wir von den erst- 
genannten Salzen den grösseren Theil im Stuhlgang wiederfinden, wohingegen die anderen durch die Nieren ausgeschieden werden.

Auch unsere Auffassungen iber Darmresorption, Nieren secretion, Lymphebildung u. s. w. würden viclleicht eine bedentende Umgestaltung erfahren mitssen.

Wenn z. B. ein Salz nnr einen geringen Widerstand findet im Darmepithelium, durch welches es vom Gewebesaft geschieden ist, wird seine Lösung letzterem gegeniuber nicht den osmotischen Druck entwickeln, der deren Gefrierpunktserniedrigung entspricht. Der Druck wird um so kleiner sein, je leichter das Salz durch die Epithelschicht dringt. So wäre erklärlich, dass eine Lösung, die nach unserer Meinung hyperisotonisch sein misste, dennoch im Darm nicht wasseranziehend wirkt, sondern sich durch das Epithelium zum Saftstrom begiebt.

Gifte, welche die Permeabilität des Darmepitheliums veränderen, ändern auch den zur Entwickelung gelangenden osmotischen Druck und damit die wasseranziehende Kraft der Lösung.

Heid en hain ${ }^{1}$ ), der bei seinen jüngsten Untersuchungen über Resorption diesen Ueberlegungen keine Rechnung trug, kam zu der Annnahme resorbirender Kräfte, wo solches vielleicht nicht nöthig war. Den Begriff: „osmotisehes Aequivalent" hat er jedoch noch nicht fahren lassen, und wo er zur Bestimmung der wirkenden osmotischen Kräfte die Gefrierpunktserniedrignng gebraucht, bedenkt er nicht, dass die Proportionalität zwischen dieser und dem osmotischen Druck allein für den Fall Geltnng hat, dass der gelöste Stoff nicht durchdringt.

Auch bei der Muskelcontraction würden osmotische Verhältnisse eine bedeutende Rolle spielen können.

Wenn in den anisotropen Schichten resp. in den Sareous elements zusammengesetzte Moleciule unter dem Einfluss des Reizes in mehrere zerfallen und die Grenzschicht zwischen isound anisotropischer Substanz auch für letztere nicht permeabel ist, so wird der osmotische Druck demzufolge in den doppeltbrechenden Schichten ansteigen, sodass diese Wasser aufnehmen auf Kosten der isotropen Substanz. Frleiden jetzt die Zerfallsprodukte eine noch weitergehende Veränderung, in Folge deren die Grenz-

1) R. Heidenhain, Nene Versuche über die Aufsangung im Dünndarm. Pflüger's Arch. Bd. 56, S. 579 ff. 
schicht ihnen den Durchgang gestattet, so verliert sich der osinotische Druckunterschied.

Die glatten Muskelzellen würden das Wasser aus dem sie umgebenden Nahrungssaft aufnehmen miissen, und die soviel schneller vor sich gehende Contraction der quergestreiften Muskelfasern würde ihre Erklärung finden in der relativ soviel grösseren Oberfläche der Grenzschicht, woselbst der Ausgleich der osmotischen Spannungen und die Diffusion stattfinden ${ }^{1}$.

Wir wollen uns jedoch nicht weiter in speculative Betrachtungen vertiefen, sondern vielmebr zu unseren Untersuchungen zuriickkehren.

Ausser den angeführten Stoffen untersuchte ich viele, bei denen die Permeabilität nicht mit Sicherheit festzustellen war. Hierzu gehören natürlich in erster Linie die, welche eine Fällung des Blutfarbstoffes oder des Protoplasmas der Blutkörperchen erzielen, wie Chromsäure und chromsaure Salze, Sublimat, Kupfersulfat, Silbernitrat u. A.

Weiter giebt es Stoffe, z. B. Erythrit, die zwar keine Fällung bewirken, aber anch nicht einer der beiden obigen Gruppen zugezählt werden können. In einer reinen Erythritlösung senken sich rothe Blutzellen anfänglich ohne Abgabe des Farbstoffes; bei längerem Stehen jedoch tritt letzterer aus. In der Kochsalz enthaltenden Erythritlösung ist noch kein Farbstoff ausgetreten, wenn die reine Erythritlösung bereits deutlich roth ist. Wir hätten es hier also mit einem Stoffe zu thun, fürr welchen die Blatkörperchen zwar permeabel sind, der aber im Vergleich mit Wasser einen grossen Widerstand zu überwinden hat.

Endlich besitzen verschiedene Stoffe eine so starke Giftwirkung, dass sowohl in wïsserigen als in Kochsalz enthaltenden Lösungen derselben sofort Blutfarbstoff austritt, wie Amylnitrit, Ammoniumeinnamylat $\mathfrak{u}$. A.

Noch bleibt uns übrig, Inosit anzuführen als einen Stoff, der, wie die wahren Zuckerarten, in die intacten Blutkörperchen nicht eindringt, sich aber von ihnen dadurch unterscheidet, dass er für diese

1) Ich will hier absolut nicht dic Bedeutung der Engelmann'schon Untersuchungen über die Wärme als Ursache der Muskelcontraction unterschätzen (Pflüger's Archiv); was hindert uns aber, eine Zusammenwirkung verschiedener Factoren anzunehmen? 
Ueber den Einflass gelöster Stoffe auf dje rothes Blutzellon etc. 107

Zellen nicht indifferent ist, sondern wie ein Gift auf dieselben einwirkt. Es sinken anfänglich in einer isotonischen Inositlösung die Blutkörperchen ohne weiteres zu Boden, doch nach einiger Zeit schwellen sie anf und lassen den Farbstoff los. Dasselbe geschieht, wenn das Inosit in einer isotonischen Salzlösung aufgelöst ist.

II.

Jetzt, da wir die Permeabilität der rothen Blutzellen für verschiedene Stoffe untersucht haben, können wir einige Untersuchungen über den osmotischen Druck von Blutkörperchen und Serum besprechen.

Die Methoden von $\mathrm{Hamburger}$ wurden schon besprochen. $\mathrm{Zu}$ einer anderen Untersuchungsweise kam ich an der Hand der neueren klinischen Methode, das Volumen der rothen Blutkörperchen durch Centrifugiren zu bestimmen. Hedin ${ }^{1}$ ), Daland ${ }^{2}$ ) und Gaertner ${ }^{3}$ ) haben hauptsächlich diese Methode ausgearbeitet. Sie kommt im Princip anf das Folgende hinaus: ein gewisses Quantum Blut wird mit einer Lösung gemischt, in welcher das Blut nicht gerinnt und der Blutfarbstoff nicht austritt; diese Mischung wird in einem calibrirten Röhrchen centrifugirt, und schliesslich hat man nur das Volum des Bodensatzes abzulesen. (Auf diese Methode komme ich später zurüick.)

Wenn der durch Centrifugiren erhaltene Bodensatz ein Maass für die Volumsumme der roten Blutzellen ist, so muss er mit diesen Zellen an Grösse zunehmen, wenn eine Verdünnungsflïssigkeit benutzt wird, worin die Blutkörperchen Wasser aufnehmen; dagegen abnehmen, wenn die Zellen an das verdünnende Medium Wasser abgeben. Beim Suchen nach einer geeigneten Vedïnnungsflüssigkeit, wobei u. A. Kaliumbichromatlösungen von verschiedener Stärke $(10-1,25 \%)$ erprobt wurden, fand Daland denn auch, dass das gefundene Volumen grösser ist bei den verdünnten, dagegen kleiner bei den stärkeren Lösungen. Hieraus zog er jedoch keine weiteren Schliusse.

Um dies einer näheren Untersuchung zu unterziehen, ver-

1) Hedin, Skand. Archiv für Physiologie. 1890.

2) Daland, Fortschritte der Medizin. IX, 20 (1891).

3) Gaertner, Berliner klin. Wochenschrift. XXIX, 36 (1892). 
fertigte ich ziemlich enge Röhren, deren geschlossenes Ende sich kugelförmig erweiterte und die ungefäbr 4 cem Inhalt batten. Ueber der Kngel war die Röhre mit einer skala versehen, die das Volum des Bodensatzes zn messen gestattete.

Defibrinirtes Blut - vielfach machte ich von Hihnerblut Gebrauch, weil solches mir täglich in grosser Menge friseh zur Verfügung. stand - wird in diesen Röbren solange centrifugirt, bis der Bodensatz nicht mehr abnimmt. Jetzt wird das Serum sorgfältig abgehoben und durch die zu nntersuchende Lösung ersetzt, die Blutkörperchen in die Flüssigkeit vertheilt und anfs Nene centrifugirt, bis das Volumen der Senkungsschicht sich gleich bleibt. Die mittlere Zeitdauer hierfür betrog $1 \frac{1}{2}-1^{3 / 4}$ Stunde. Die Umdrehungsgeschwindigkeit wurde nach den Bewegungen eines Pendels regulirt und aus naheliegenden Gründen möglichst gross genommen (ca. 2400 Umdrehungen pro Minute der M u encke'sehen Centrifuge).

Schon bei den ersten Versuchen war ersichtlich, dass das Volumen des erbaltenen Niederschlages um so grösser war, jemehr die Concentration der Verdiunnungsflüssigkeit abnahm, bis endlich beim Austreten des Blutfarbstoffes die Abweichungen unregelmässiger wurden.

Nimmt man defibrinirtes Blut, schüttelt es durch und centrifugirt einige Proben davon, so ergiebt sich, dass in den verschiedenen Röhrchen die Volumina des Sediments den benutzten Blutmengen proportinal sind. Bei grleicher Umdrehungsgeschwindigkeit ist somit das relative Sedimentvolum eine constante Grösse gleichwie das Volum der körperlichen Blutbestandtheile selbst.

Ein ganz ähnliches Resultat erbält man, wenn das Serum mehr oder weniger vollständig durch eine geeignete Salzlösung ersetzt worden ist.

Wird einer Kochsalzlösung ein gewisses Quantum Harnstoff oder Alkohol zugefügt, von letzterem jedoch nur so wenig, dass die Wirkung des Giftes nicht in den Vordergrund tritt, so hat dies auf das erhaltene Sedimentvolumen keinen merkbaren Einfluss.

In vier Röbren wird defibrinirtes Hühnerblut centrifugirt, das Serum ersetzt durch angefähr isotonische Kochsalzlösung, welcher resp. $0,1,1,1$ und $1,2 \%$ Harnstoff hinzugefügt ist, und ron neuem centrifugirt bis ein constantes Volum des Bodensatzes erreicht ist. 
Setzen wir das nach einmaligem Centrifugiren erhaltene Sedimentvolum $=1$, so finden wir die folgenden Verhältnisszahlen:

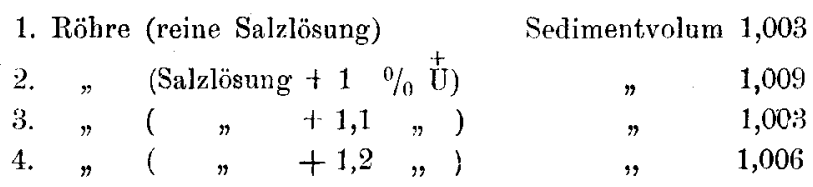

Der Harnstoff wirkt also sicherlich nicht wasserentziehend.

Jetzt war es von Wichtigkeit, zu untersuchen, ob wirklich dio Lösung eines nicht durchdringenden Salzes, in der dasselbe Sediment-Volumen wie im Serum erhalten wurde, anch mit dem Serum isotonisch sei. $\mathrm{Zu}$ diesem $\mathrm{Zweeke}$ wurden sowohl vom Serum als von der urtersuchten Salzlösung die Gefrierpunktserniedrigung bestimmt, wobei ich von B e ck m a n n's ${ }^{1}$ ) Apparat Gebrauch machte.

1) Heidenhain (Neve Versuche über die Aufsaugung im Dünndarm l. c. S. 587) missbilligt diese Methode in ziemlich hohem Grade, dem ich allerdings nicht beistimmen kann. Dass der Nullpunkt des dort beschriebe. nen Thermometers veränderlich ist, ist nach meiner Meinung auf die Zuverlässigkeit der Bestimmungen nicht von grossem Einfluss, wenn man vor und nach jedor nicht zu langen Reihe von Wahrnehmungen den Nullptnkt feststellt. Selbst bei Thermometern mit constantem Nullpunkt muss solches ab und au geschehen, sowohl für die Controle des für die Lösungen gebrauchten destillirten Wassers, als des Umstandes halber, dass bei allen Thermometern der Nullpunkt sich auf die Dauer verändert.

Bei Serienbestimmungen, die 1-2 Stunden dauerten, fand ich jedoch selten grössere Unterschiede als $0,002-0,003^{\circ} \mathrm{C}$.

I) von Heidenhain gerügte Unbeständigkeit der Resultate konnte ich ebensowenig constatiren. Ich finde im Gegentheil eine sehr gute Uebereinstimmung zwischen verschiedenen Bestimmungen derselben Constanten, so z. B. für :

Kaliumchlorid 1,30\% am 10. 4. $94: 0,626$, am 18. 8. $94: 0,626$.

Natriumchlorid $0,90 \%$ am 31. 3. $94: 0,554$, am 6. 6. $94: 0,561$, am 14. $6.94: 0,551$.

Dass verschiedene Beobachter verschiedene Resultate erzielen, liegt nach meiner Meinung vielmehr an einem Nichtcontroliren des Thermometers als an einem Mangel in der Methode selbst, obwohl ich gerne zugebe, dass kleine, persönliche Abweichungen vorkommen müssen, abhängig vom Fisquantum, welches man auskrystallisiren lässt. Da ich jedoch jederzeit Gefrierpunktsbestimmungen vrrschiedener Lösungen vergleiche, fällt der persönliche Fehler fast rollständig weg. 
Bei diesen Untersuchungen erlangte ich sebr wut ibereinstimmende Ziffern, z. B.

9. 6. 94. Pferdeblut.

$0,92 \%$ NaCl-Lösung giebt eine Zusammenziehung von beinahe 1 (Skalentheil).

$0,88 \%$ NaCl-Iösung giebt eine Ausdehnung von 1 .

Die isotonische lösung jst also ungefähr $0,90 \%$.

Gefrierpunktserniedrigung des Serums $=0,549^{\circ} \mathrm{C}$.

Gefrierpunktserniedrigung der $0,90 \%$ NaCl-Lösung $=0,561 \%$ C. Isotonische I,ösung $=\frac{549}{561} \times 0,90=0,88 \%$.

14. 6. 94. Pferdeblut.

$0,90 \% \mathrm{NaCl}$ giebt ein Einschrumpfen von $1 / 4$.

Gefrierpunktserniedrigung des Serums $=0,549^{\circ}$ C.

Gefrierpunktserniedriguug der Salzlösung $=0,550^{\circ} \mathrm{C}$.

15. 6. 94 . Hühnerblut.

$0,98 \% \mathrm{NaCl}$ giebt ein Finschrumpfen von $1 / 4$

$0,96 \% \mathrm{NaCl}$ giebt eine Ausdehnung von $1 / 4$.

Gefrierpunktserniedrigung des Serums $0,619^{\circ} \mathrm{C}$.

Gefrierpunktserniedrigung der $0,98 \%$ NaCl-Lösıng $0,602 \% \mathrm{C}$.

18. 8.94 .

$1,35 \% \mathrm{KCl}$ giebt ein Einschrumpfen von 1.

$1,30 \% \mathrm{KCl}$ giebt keine Veränderung des Volumens.

$1,25 \% \mathrm{KCl}$ giebt eine Ausdehnung von 1 .

Gefrierpunktserniedrigung des Serums $=0,624^{\circ} \mathrm{C}$.

Gefrierpunktserniedrigung von $1,30 \% \mathrm{KCl}=0,6266^{\circ} \mathrm{C}$.

13. 9. 94 .

$10,2 \%$ Milchzuckerlösung giebt eine Schrumpfung von noch nicht $1 / 4$.

Gefrierpunktserniedrigung des Serums $0,617^{\circ} \mathrm{C}$.

Gefrierpunktsernied̉rigung der Milchzuckerlösung (aus der einer verdünnteren Lösung berechnet) $0,600^{\circ} \mathrm{C}$.

Diese Beispiele würde ich leicht mit mehreren, auch für andere Stoffe als $\mathrm{NaCl}$, bereichern können; weil jedoch kürzlich eine grosse Zahl dergleichen Untersuchungen durch $\mathrm{I}$ edin ${ }^{1}$ ) publicirt wurden, sebe ich von diesem Vorhaben ab.

Hat die Theorie mit den bis jetzt besprochenen Thatsachen sich leicht in Uebereinstimmung bringen lassen, dass nämlich die rothen Blutkörperchen für Wasser leicht permeabel sind, nicht oder

1) Dieses Archiv. Bd. 60. 
nur schwer für viele andere Stoffe, und dass sie in den Lösungen dieser Stoffe, je nachdem diese byp- oder hyperisotonisch sind, Wasser aufnehmen oder abgeben, solass ibr Volnmen durch den osmotischen Druck der sie umgebenden Lösung bedingt wird, so miissen wir jetzt einen scheinbar hiermit im Widerspruch stehenden Versuch besprechen.

Wenn wir Blut oder, was besser ist, den durch Centrifugiren erlangten Bodensatz, der hauptsächlich aus rothen Blutkörperehen besteht, mit Wasser verdïnnen und von der Mischung, in welche das Hämoglobin ansgetreten ist, die Gefrierpunktsernicdrigung bestimmen, so gelangen wir zu einem niedrigeren Werth, als dem des in glcichem Maasse verdünnten Serums.

H a $\mathrm{mb}$ u $\mathrm{rg}_{\mathrm{g}} \mathrm{er}^{1}$ ), der diese Erscheinung zuerst bemerkte, zog darans den, bei oberflächlicher Betrachtung richtig scheinenden, Schluss, dass in den Blutkörperehen ein geringerer osmotischer Druck, als im Serum herrsche. Dies ist jedoch bei freiem Wasseraustausch auf die Daner natïrlich unmöglich. Die Ursache dieser Erscheinung, welche also anderswo gesucht werden muss, lïsst sich durch folgende Ueberlegung finden.

Dic Blutkörperchen, welehe doch ohne Zweifel als Zellen anfgefasst werden müssen, bestehen nicht aus einer äusserst diinnen Wand mit cinem flüssigen Inhalt, sondern sie mïssen vielmehr als eine lebende Substanz, in der Nahrungssaft vorhanden ist, betrachtet werden. Soweit mir bekaunt, ist eine derartige Struktnr für die Blutkörperchen noch nicht erwiesen; doch die Analogio mit andern Zellen, bei welchen eine solche Differentiation mit Hiilfe des Mikroskopes nachgewiesen werden kann, nöthigt uns zu dieser Annahme.

Nun bleibt bei der Behandlung der Blutzellen mit Wasser ein Theil übrig, der nicht in Auflösung ubergeht (Oikoid, Stroma : Rollet, Brue eke).

Wir haben demnach in der lebenden rotben Blutzelle sowohl als in der Mischung, in welche das Hämoglobin ausgetreten ist, einen fïr den osmotischen Druck nicht in Betracht kommenden Theil. Wenn wir also ein bestimmtes Volumen rother Blutzellen (a) mit einem bestimmten Volumen Wasser (b) mengen, muissen

1) Hamburger, Recueil des travanx chimiques des Pays-bas. XIII, 2, p. 76 . 
wir für die Berechnnng des osmotischen Druckes nicht die Verdiunnung $\frac{a}{a+b}$, sondern $\frac{a-p}{a-p+b}$ annehmen, worin $p$ den nicht aufgelösten Theil der Blutzellen angiebt. Versäumen wir dies, so fällt unsere Ziffer kleiner aus, als mit der Berechnung überein. stimmt.

Ist diese Betrachtung richtig und diirfen wir ebenfalls annelumen, dass dabei nicht ein bemerkenswerthes Quantum Wassers oder lösbarer Stoffe freikommt oder gebunden wird, so wird, wenn wir die rothen Blutzellen in ihrem eigenen Serum auflösen, die Gefrierpunktserniedrigung unverändert bleiben. Es stellte sich heraus, dass dies auch wirklich der Fall ist.

So fand ich für Hühnerblut:

Serum $\left.d^{1}\right)=0,61^{0} \mathrm{C}$;

Blut, nach wiederholtem Gefrieren und Aufthauen $A=0,61^{\circ} \mathrm{C}^{2}$ ).

Wir siod demnach zu der Annahme berechtigt, dass der in den rothen Blutzellen enthaltene Saft den gleichen osmotischen Druck hat, wie das Serum, während der Rest des I3lutkïrperehens als organisirte, nicht gelöste Substant hetrachtet werden muss.

Wir können sogar berechnen, in welchem Volumverhültniss beide zu einander stehen, vorausgesetzt, dass das Verbältniss des Serumvolums zum Blutvolum bekannt sei.

Letateres können wir nach der Methode von Bleibtre $\mathfrak{u}^{3}$ ) oder dergleichen bestimmen, wobei wir darauf achten miissen, mit isotoniseher Mischflüssigkeit zu arbeiten ${ }^{4}$ ).

Ist auf diese Weise das relative Serumvolum $x$ bekannt, so haben wir weiter, wenn eine Quantität Blut a mit einer Quantität destillirten Wassers $b$ gemengt wird, und $p$ das Volumverhältniss

1) Bezeichnung für Gefrierpunktsdepression.

2) $\mathrm{Da}$ in der dunkelrothen, fast undurchsichtigen Blutflüssigkeit schwerlich zu beobachten ist, ob viel oder wenig Eis gebildet, wurde hicr nur bis auf $1 / 100^{0}$ genau bestimmt.

Dass in der That in Folge des wiederholten Gefrierens und Aufthauens die Blutkörperchen ihren Farbstoff abgegeben hatten, geht daraus hervor, dass bei entsprechender Verdünnung der Blutflüssigkeit mit isotonischer Kochsalzlösung eine durchsichtige, intensiv rothgefürbte Flüssiokeit erhalten wurde, in weleher sich entfärbte Blutkörperchen zu Boden senkten.

3) M. Bleibtreu, dieses Archiv Bd. 57 и. 58.

4) C. Eykman, ebendaselbst Bd. 60 . 
des gelösten Theils der Blutzelle zur ganzen Zelle darstellt: $a x$ Serum und $a(1-x)$ Blutzellen; von letzteren ist $a(1-x) p$ anfgelöst; im Ganzen ist also $a x+a(1-x) p$ Lösung im Blut vorhanden; diese wird mit destillirtem Wasser $(b)$ vermischt.

Ist die Gefrierpunktserniedrigung des Serums $\Delta_{1}$, die des verdiinnten Blutes $\mathcal{A}_{2}$, so gilt das Verlältuiss:

$$
\begin{aligned}
\Delta_{1}: \Delta_{2}=b+a x+(1-x) p: a x+a(1-x) p, & \\
& \quad \text { oder } p=\frac{\Delta_{2}(a x+b)-\Delta_{1} a x}{\left(\Delta_{1}-\Delta_{2}\right)(a-a x)} . ., . .
\end{aligned}
$$

$\mathrm{Als}$ Beispiel führen wir einige Bestimmungen an.

20. 1. 95. Pferdeblut.

$12 \frac{1}{2} \mathrm{~cm}$ Blut werden durch Vermischung mit dem gleichen Volum destillirten Wassers lackfarbig gemacht.

Gefrierpunktscrniedrigung des Serums $A_{1}=0,561$.

Gefrierpunktserniedrigung der Mischung $A_{2}=0,240$.

s. $\mathrm{G}$. des Blutes $=1,055$.

s. G. des Serums $=1,0272$.

s. G. einer $0,9 \% \mathrm{NaCl}$-Lösung $=1,0063$.

$25 \mathrm{ccm}$ Blut centrifugirt, hiervon $10 \mathrm{ccm}$ Serum abgehoben und durch $10 \mathrm{ccm} 0,9 \%$ NaCl-Iösung ersetzt, umgerührt und wieder centrifugirt.

s. (i. der jetzt erhaltenen Serumflüssigkeit $S=1014,1$.

Setzen wir das Serumquantum in $25 \mathrm{ccm}$ Blut $=y$, so ist:

$$
\begin{aligned}
& (y-10) 1,0272+10 \times 1,0063=1,0141 y \\
& y=16 \text {. }
\end{aligned}
$$

Wir haben also $x=\frac{16}{25}$ oder $64 \%$ Serum.

In Formel 1 substituirend, bekommt man also, wcil $a=b$ :

$$
p=\frac{A_{2}(x+1)-A_{1} x}{\left(A_{1}-A_{2}\right)(1-x)}=\frac{0,240\left(\frac{1}{2} 6+1\right)-0,561\left(\frac{16}{2}\right)}{(0,561-0,240)\left(1-\frac{16}{2} 6\right)}=0,33 .
$$

22. 1. 95. Hühnerblut.

s. G. Blut $=1,0498$. Serum $A_{1}=0,620$.

s. G. Serum =1,0206. Mischung (gleicher Volumina Blut und

s. G. $0,97 \% \mathrm{NaCl}=1,0070$. Wasser) $\boldsymbol{A}_{2}=0,291$.

$25 \mathrm{ccm}$ centrifugirtes Blut und hiervon $10 \mathrm{~cm}$ Serum algehoben und durch $10 \mathrm{cem} 0,97 \% \mathrm{NaCl}-L o ̈ s u n g ~ e r s e t z t$, gemischt und wieder centrifugirt; s. G. der auf diese Weise erhaltenen Flüssigkeit $=1,0127$.

Hierbei finden wir für $y$, in gleicher Weise wic oben berechnet,

$$
\text { und } \begin{gathered}
y=17, \text { also } x=0,68, \\
p=0,64 .
\end{gathered}
$$

E. Pflüger, Arehiv f. Physiologie. Bd. 6 . 
23. 1. 95. Hühnerblut.

s. G. $0,968 \%$ NaCl-Lösung $=1,0069$.

s. G. Serum $=1,0193$.

A. $121 / 2$ ccm Blut gemischt mit $13 \mathrm{ccm}$ NaCl-Lösung $(0,968 \%$ (erste Verdünnung) centrifugirt; s. G. obenstehender Flüssigkeit $=1,0118$.

B. $15 \mathrm{ccm}$ Blut mit $10 \mathrm{~cm} 0,968 \% \mathrm{NaCl}$ verdünnt, centrifugirt (zweite Verdünnung); s. G. obenstehender Flüssigkeit $=1,0131$.

Gefrierpunktserniedrigung des Serums $A_{1}=0,600^{\prime \prime} \mathrm{C}$.

Gefrierpunktserniedrigung einer Mischung von $12 \% \mathrm{eem}$ Blut und $121 / 2 \mathrm{~cm}$ Wasser $A_{2}=0,278^{0} \mathrm{C}$.

Für die erste Verdünnung $(\Lambda)$ finden wir:

$$
\begin{aligned}
& x=0,68, \\
& p=0,58 .
\end{aligned}
$$

Für die zweite Verdünnung (B):

$$
\begin{aligned}
& x=0,67, \\
& p=0,585 .
\end{aligned}
$$

18. 2. 95. Pferdeblut.
s. G. Blut = 1,0553.
$A_{1}=0,520^{\circ} \mathrm{C}$.
s. G. Serum $=1,0266$.
$A_{2}=0,226^{\circ} \mathrm{C}$.

s. G. Salzlösung $=1,0063$.

$25 \mathrm{~cm}$ Blut mit $25 \mathrm{~cm} 0,9 \% \mathrm{NaCl}-\mathrm{cösung}$ vermischt und centrifugirt: obenstehende Flüssigkeit hat ein s. G. $=1014,5$. Hieraus finden wir:

$$
\begin{aligned}
& x=0,67, \\
& p=0,35 .
\end{aligned}
$$

Der als Lösnng zu betrachtende Theil der Blutkïperchen des Pferdeblutes beträgt 0,33-0,35 ihres Volumens. Fiir Hiuhnerblut ergeben sich höhere Ziffern, nämlich 0,585-0,64.

\section{III.}

Nachdem wir jetzt gesehen, dass nicht allein die Blutkörperchen selbst, sondern auch der durch Centrifugiren erhaltene Bodensatz ihre Grösse wechseln mit der osmotischen Spannung der Zwischenflüssigkeit, so können wir zu der Frage äbergehen, die auch Hedin sich jüngsthin stellte: Können wir die Centrifugirmethode zum Messen des gemeinschaftlichen Volumens der rothen Blutkörperchen gebrauchen, und ist sie klinisch brauchbar? Dass das Volumen der Senkungsschicht eine einfache Function von Anzahl und Volumen der Blutzellen ist, wird nach dem Vorhergehenden wohl Niemand bezweifeln; jedoch muss man daffir Sorge tragen, dass durch die eventuell zu brauchenden Verdiinnungs- 
flüssigkeiten keine Veränderungen im Volumen der rothen Blutkörpcrehen zuwege gebracht werden.

Wollen wir das Volumen der körperlichen Bestandtheile im circulirenden Blute kennen lernen, so muss das Defibriniren umgangen werden, weil wir nicht wissen, wieviel Blutzellen durch diese Operation entfernt werden

Frühere Forscher suchten die Gerinnung durch Beimischung von Sublimat- oder Bichromatlösung hintanzuhalten. Indess, weil diese Stoffe Eiweiss aus dem Blute niederschlagen und schädigend auf die Blutkörperchen einwirken, sind sie für unseren Zweck nicht geeignet.

Die Volumina des Bodensatzes, die erzielt wurden, falls Pröbchen von demselben Blut mit der gleichen Sublimat- oder Bichromatlösung gemischt und centrifugirt waren, erwiesen sich als sehr verschieden von einander.

Bei mikroskopiseher Betrachtung stellte sich zudem heraus, dass die rothen Blutzellen ziemlich weitgehende Veränderungen erlitten hatten.

Hieraus erhellt, dass die von $\mathrm{H}$ edin, Daland, Gaertner u. A. angegebenen Verdünnungsflüssigkeiten nicht zweckdienlich sind, und wir uns deshalb nach einer anderen umsehen müssen.

Meine Versuche haben nun ergeben, dass man sich zu dem erwähnten Zweck mit Vortheil einer isotonischen Kochsalzlösung bedienen kann, der behufs Hintanhaltung der Gerinnung des Blutes eine kleine Menge Oxalat beigemischt ist. Weil Ammoniumoxalat in die rothen Blutzellen eindringt und somit nicht wasserentziehend auf dieselben einwirkt, kann es in Substanz zngesetzt werden. Will man, wie wir es meistens gethan, Natriumoxalat benutzen, so muss davon eine isotonische Lösung bereitet und der Kochsalzlösung hinzugesetzt werden.

Mit defibrinirtem Blute angestellte Controlversuche ergaben, bezüglich der Brauchbarkeit der Oxalatkochsalzlösung als Mischflïssigkeit, sehr zufriedenstellende Resultate. Was die durch das Oxalat gefällte Kalkmenge anbetrifft, so ist dieselbe zu gering, als dass sie für die Genauigkeit der Versuchsergebnisse in Betracht kommen dürfte.

Es war zunächst die mit dem Menschenblut isotonische Lösung zu ermitteln. Ich ging dabei folgendermaassen zu Werke: Mehrere Blutpröbchen, durch Einstich in die Fingerbeere erhalten, 
werden je mit einer kleinen Menge einer für jedes Prôbchen verschieden starken Salzoxalatlösung gemischt. Alsdann wird centrifugirt, bis der Bodensatz nicht mehr an Volum abnimmt, die obenstehende Flissigkeit abgehoben und durch ein Uebermaass der urspriugglich zugesetzten Lösung ersetzt; darauf wird der Bodensatz in der Fliissigkeit vertheilt und aufs Neue centrifugirt. Jetzt hat man darauf zu achten, bei welcher Concentration der Verdïnnungsfliissigkeit das Volum des Bodensatzes sich nicht oder am wenigsten geändert zeigt.

Es sei der wirksame osmutische Druck der Verdunnungsflüssigkeit $a$, der des Blutplasua $b$, die urspriunglich vor'handene Quantität Blutplasma + dem gelösten Theile der rothen Blutzellen $q$, so hat man für die Mischung einen wirksamen osmotischen Druck $=\frac{a+b q}{1+q}$.

Wurde nun beim zweitnächsten Centrifugiren das gleiche Volumen erzielt, wie das erste Mal, so musste die Verdiinnngsfliissigkeit denselben Drack, wie die Mischang ausiiben, also:

$$
\frac{a+b q}{1+q}=a \text { sein. }
$$

Dieses kann, weil $q>0$, allein der Fall scin, wenn $a=b$, die Verdiunnungsflissigkeit also isotonisch mit dem Plasma war.

Solchermaassen wurde gefunden, dass Menschenblut ungefähr isotonisch ist mit $0,88-0,84 \% \mathrm{NaCl}$-Lösung ${ }^{1}$ ).

Der Controle halber führte ich noch einige Gefrierpunktsbestimmungen an Menschenblut aus. Das Blut wurde durch Aderlass gewonnen und in einer abgewogenen Menge NatriumchloridOxalatlösung aufgefangen.

Das Weitere ergiebt sich aus den nachstehend beschriebenen Versuchen.

8. 2. 95 .

s. G. der Natriumohlorid-Oxalatlösung $=1,0072$.

Menge, $\quad " \quad \# \quad=6,6993$ g oder 6,698 cem.

$A \quad " \quad " \quad, \quad=0,335^{\circ} \mathrm{C}$.

8. G. des Blutes (Tropfenmethode $\mathrm{Ham}$ -

$$
\text { merschlag) }=1,059 \text {. }
$$

1) Eykman, Virchow's Archiv, Bd. 143. 
Menge des Blutes

1 der Salzlösung-Serummischang
$=39,682 \mathrm{~g}$ oder $37,489 \mathrm{ccm}$.

$=0,506 \mathrm{C}$.

Man hat jetzt, falls $t y$ dic Gefricrpunitsernicdrigung des Blutes ist:

$$
6,628 \times 0,335+37,489 \times A p=(6,628+57,459) 0,506,
$$

woraus

$$
\alpha p=0,533 \text {. }
$$

11. 2. 95 .

s. G. der Natriumchlorid-Oxatatlösung $=1,0124$.

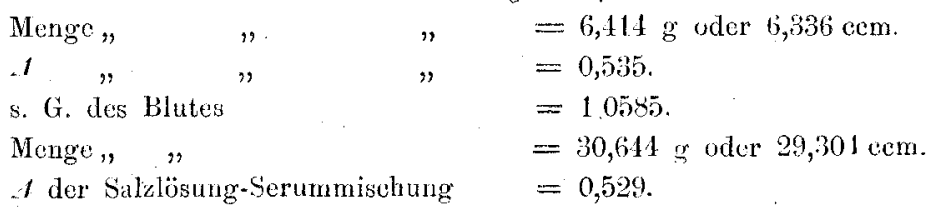

Daraus berechnet man $4 p$ :

$6,336 \times 0,535+1 p \times 29,304=(6,336+29,304) 0,029$

$$
\Delta p=0,528 \text {. }
$$

Wir findeu demnach, dass die Gefrierpunktserniedrigung des Menschenbluts in den zwei Versuchen $0,528^{\circ}$ bis $0,533^{\circ} \mathrm{C}$. betrug. Die Versuchsresultate sind insofern mit einem Fehler behaftet, als bei der Berechn̄ung das Blut im ganzen als Lösung betrachtet, der feste, organisirte Theil der Blutkörperchen somit vernachlassigt wurde. Eine entsprechende Correctur vorzunchmen wäre nur möglich, falls das relative Volum des letateren bekannt wäre. Nehmen wir dies nach Analogie des für das Pferdeblut ermittelten Werthes auf $65 \%$ der Blutkörperchen oder $26 \%$ des Gesammtblutes an, so ergiebt sich, dass im ersten Versuch $A p=0,547$ anstatt 0,533 betragen wïrde. Im zweiten Versuch ist die Correctur fast gleich Null.

Für Kochsalzlösungen von $0,8-0,9 \%$ fanden wir $d=0,510$ bis $0,550^{\circ} \mathrm{C}$.

Nach der Bestimmung der Gefrierpunktserniedrigung ist mithin das Menschenblut isotonisch mit Kochsalzlösung von 0,845 bis $0,892 \%$.

Diese Werthe stimmen gut ïberein mit denjenigen, die nach der Centrifugirmethode erbalten wurden.

Noch bleibt uns zu untersuchen übrig; wie sich das Sedimentvolum zum wirklichen Volum der körperlichen Blutbestandtheile verhält.

Mehrere Wege führeu hier zum Ziel.

Ich bestimmte das Porenvolum einer gegebenen Menge des Sediments, indem.ich ermittelte, in welchem Verhältniss die die 
Poren ausfüllende Zwischenflüssigkeit durch Beimischung eines bestimmten Quantums einer zweiten isotonischen Flüssigkeit verdünnt wurde. Die Versuchsanordnung ist, wie folgt.

Zuerst wird mit Zuhiilfenahme der Centrifuge das Serum möglichst vollständig aus dem Blut entfernt und durch isotonische Kochsalzlösung ersetzt. Jetzt wird die Blutprobe solange centrifugirt, bis das Volum des Bodensatzes sich nicht mehr ändert. Die obenstehende Flüssigkeit wird alsdann sorgfältig bis auf die letzten Spuren abgehoben und zur Bestimmung ibres Chlorgehaltes anfbewahrt. Nun wird das Sediment tüchtig mit einer genan abgemessenen Menge einer isotoniscben Milchzuckerlösung vermischt, nochmals centrifugirt, und danach die obenstehende Flüssigkeit auf ihren Chlorgehalt untersucht.

Sei $a$ die Menge des Sediments, $p$ das relative Porenvolum desselben, $m$ der Chlorgehalt der obenstehenden Kochsalzlösung, $n$ jener der obenstehenden Milchzuckerlösung und $b$ die Mengre, die von letzterer zugesetzt wurde. Fs ergiebt sich dann folgende Gleichung:

worans :

$$
\begin{aligned}
a p \times m & =(b+a p) n, \\
p & =\frac{b n}{a(m-n)} .
\end{aligned}
$$

Die Versuche wurden mit Hïhnerblut angestellt.

\section{1. 94 .}

Hïhncrblut in 4 calibrirten Röhren centrifugirt und weiterhin in der obcn beschriebenen Weise behandelt.

Die vier Blutproben ergeben die nachstehenden Werthe für das relative Porenvolum:

$$
\begin{gathered}
\text { I. } 22.8 \%, \quad \text { II. } 20,5 \%, \quad \text { III. } 18,2 \%, \quad \text { IV. } 19,5 \% \text {. } \\
\text { Mittel } 20,2 \% \text {. }
\end{gathered}
$$

4. 1. 94. Versuchsanordnung wie oben.

Die Ergebnisse der Bestimmung des Porenvolums sind:
I. $22 \%$,
II. $21,8 \%$,
III. $23 \%$, IV. $21,2 \%$.
Mittel 22,0\%.

5. 1. 94. Ausführung des Versuchs wie oben.

Das Porenvolum der vier Blatproben beträgt:
I. $15,1 \%$,
II. $16,7 \%$,
III. $15 \%$,
IV. $16,8 \%$.
Mittel 15,9\%.

In drei Versuchen beträgt somit das Porenvolum 20,2, 22 und $15,9 \%$ des Sedimentvolums.

Ich habe auch zwei Bestimmungen gemacht, wobei die Milch- 
Ueber den Einfluss gelöster Stoffe auf die rothen Blutzellen etc. 119

zuckerlösung anstatt der Kochsalzlösung und umgekehrt benutzt wurde. Der Milchzuckergehalt wurde in diesen Versuchen mittels Fehling'scher Lösung bestimmt. Für das Porenvolum fanden wir hier $18,5-19,5 \%$.

Als Mittel aller Beobachtungen haben wir demnach 19,2\%. In Anbetracht der bei diesen Verstehen so mannichfachen Fehlerquellen sind die Abweichungen vom Mittelwerth ziemlich zufriedenstellend.

Man kann das Porenvolum anch ermitteln, indem man nach der Bleibtre u'schen Methode das wirkliche Volum der körperlichen Blutbestandtheile bestimmt und vom Sedimentvolum abzieht. Aus Eykman's diesbeziiglichen Untersnchungen ${ }^{1}$ ) ergeben sich folgende Werthe:

$$
\begin{aligned}
& \text { Für Hühnerblut . . . 15\% } \\
& \begin{array}{llr}
\text { "Schweineblut. . . } 16, \\
\text { " Pferdeblut . . . } 7,
\end{array} \text { des Sedimentvolums. } \\
& \text { "Menschenblut . . 10, }
\end{aligned}
$$

Wie der genannte Forscher mit Recht hervorhebt, ist das Porenvolum in den untersuchten Fällen zu gering, als dass sogar relativ starke Schwankungen desselben einen erheblichen Fehler in der Bestimmung des Sedimentvolums veranlassen könnten.

Nach Obigem möchte ich mein Urtheil ïber die Centrifugirmethode dahin zusammenfassen, dass sie sich bei der Untersuchung des Bluts in mancher Hinsicht sehr brauchbar erweist, und dass die weniger zufriedenstellenden Resultate, die von Andern damit erzielt wurden, nicht der Methode selbst, sondern einer nicht zweckentsprechenden Anwendung derselben zuzuschreiben sind.

1) Dieses Archiv Bd. 60 und Virchow's Archiv Bd. 143. 